\title{
Fighting climate change in the air: lessons from the EU directive on global aviation
}

Combatendo a mudança climática nos ares: as lições da diretiva da UE para a aviação global

NICOLE DE PAULA DOMINGOS

Rev. Bras. Polít. Int. 55 (special edition): 70-87 [2012]

\section{Introduction}

In the last decade, concerns with the increase of emissions in the aviation sector augmented considerably among scientist and policymakers. In the 1990s, the Intergovernmental Panel on Climate Change (IPCC) stated that the total contribution of aircraft emissions of carbon dioxide $\left(\mathrm{CO}_{2}\right)$ was around $2 \%$. Today, despite the improvement in fuel efficiency and new technologies, this industry is expected to grow considerably. ${ }^{1}$ It is estimated that the aviation sector is now contributing to almost $5 \%$ of global emissions and are expected to double or triple by 2050 if no action is taken, jeopardizing the $2{ }^{\circ} \mathrm{C}$ target. ${ }^{2}$

More importantly, this industry has been one of the most rapidly growing sources of $\mathrm{CO}_{2}$. In the European Union (EU), for example, emissions from aviation fuels expanded $80 \%$ from 1990 and $2009 .{ }^{3}$ In an attempt to cope with this problem, the EU has recently decided to extend its Emissions Trading Scheme (ETS) to include aviation. However, many countries and airline associations powerfully contested the new Directive.

To contextualize, since January 2012, the EU compels all airlines to be accountable for its greenhouse gas (GHG) emissions when landing in or taking

\footnotetext{
* Ph.D. candidate in Political Science, Institut d'Etudes Politiques de Paris (Sciences-Po) and visiting fellow at the Center for Transatlantic Relations, as part of the Paul H. Nitze School of Advanced International Studies (SAIS), Johns Hopkins University, Washington, D.C. (nicole.depauladomingos@sciences-po.org). The author would like to thank CAPES Foundation for the financial support.

1 Available at <http://www.ipcc-nggip.iges.or.jp/public/gp/bgp/2_5_Aircraft.pdf>.

2 Grounded: How ICAO failed to tackle aviation and climate change and what should happen now. Published to coincide with the ICAO Triennial Assembly, Montreal September-October 2010. 2010 European Federation for Transport and Environment AISBL.

3 LEGGETT, Jane; ELIAS, Bart; SHEDD, Daniel. 2012. Aviation and the European Union's Emission Trading Scheme. CRS Report for Congress.
} 
off from EU airports independently of nationality, flights' origin and destination. ${ }^{4}$ To illustrate the general dissatisfaction, China's top negotiator Xie Zhenhua said that "this decision by the EU will seriously jeopardize [our efforts to] tackle the international efforts to climate change." Interestingly, China was not alone. In fact, after the approval of the new legislation, the EU found itself isolated. A coalition of countries, notably the Brazil, Russia, China and South Africa group (BRICS) and the United States joined forces to take measures against Europe. ${ }^{6}$

The US, in particular, showed vehement rejection. One example can be found in a letter, signed by Hillary Clinton and Ray Lahood (Transportation Secretary), objecting the fact that international airlines are required to transmit to the EU information on their emissions. ${ }^{7}$ The letter urged the EU to re-engage with the world and stated that "absent such willingness on the part of the EU, we will be compelled to take appropriate action." ${ }^{8}$ Nevertheless, on the other side of the Atlantic, Connie Hedegaard, EU Climate Commissioner, declared following the approval of the new law: "After a crystal-clear ruling today, the EU now expects US airlines to respect EU law as the EU respects US law." "

From this episode, it became clear that while some highlight the positive aspects of the EU's measure, others pungently condemn it for being illegal, unfair and unilateral. Given this binary perception, this paper interrogates why the EU's directive was so severely criticized, despite its apparent degree of environmental coherence. It argues that concerns with competitiveness and risks of legal inconsistency at the WTO are important elements to this conundrum. However, they are insufficient to explain the reasons for an isolated Europe. Beyond the aforementioned aspects, I suggest that the method chosen by the EU to deal with the aviation emissions was perceived inappropriate, mainly because it was viewed as an imposed solution to the rest of the world. Therefore, I claim that this conflict

4 This rule is valid for cargo and passengers flights including EU operators, non EU-members Norway and Iceland and non-EU airlines. However, certain types of flights are excluded: military aviation; search and rescue flights; state flights transporting third countries' head of states, heads of governments, and ministers; and police flights. 5 India, China attack EU on airline carbon tax. February 14, 2012. Available at <http://www.eubusiness.com/ news-eu/india-basic-climate.f75> (last access July 2012).

6 "India, along with other key countries, like China, Brazil, the US and Russia had agreed to a basket of actions against EU if the latter does not back off. The committee of secretaries agreed to take those measures in sequential manner upgrading the offensive against EU." After aviation tax, EU mulls carbon levy on shipping. Available at $<$ http://articles.timesofindia.indiatimes.com/2012-04-02/india/31274958_1_carbon-tax-eu-decision-chineseairline> (last access July 2012).

7 Available at <http://www.europolitics.info/externa-policies/ecj-aviation-emissions-ruling-sharply-dividesstakeholders-art321934-44.html>.

8 International airlines will be charged for carbon emissions, EU court rules. December 21, 2011. Available at <http://www.guardian.co.uk/environment/2011/dec/21/international-airlines-carbon-emissions> (last access June 2012).

9 US voices “objections” to EU aviation emissions ruling. Published December 22, 2011 - Updated January 2, 2012. Available at <http://www.euractiv.com/transport/us-voices-objections-eu-aviation-news-509893> (last access July 2012). 
has more to do with a normative divide than with a substantive divergence on what should be done in regards to aviation emissions.

My analysis is based on present literature about competitiveness and the links between trade and climate, but gives particular weight to an empirical assessment based on extensive dialogues with numerous stakeholders and the participation at roundtables relevant to the topic. ${ }^{10}$ The paper is divided in three parts. First, it presents the scope of the Directive in a historical perspective. Second, it explores the EU's measure through three different angles: legal, economical and political. The third and final part explores some possible solutions to overcome this conflict.

\section{The EU's strategy to cope with climate change: stuck between insufficient global progress and fears of carbon leakage}

At the heart of the debate on how to manage emissions from the aviation sector lies a broader and growing concern related to the interface between trade and climate change. While the EU's decision is unique for including non-European airlines into the EU scheme, it is only one example among several possibilities dealing with carbon leakage. ${ }^{11}$ This problem refers to countries that are taking strong measures to internalize the costs of carbon emissions, but could be exposed to unfair conditions of competitiveness comparing to countries "carbon heavens." That is, because of loose regulatory frameworks, some industries could move to other countries in quest of reduced environmental burden. In order to cope with this risk, mainly the EU and the US are considering the use of two mechanisms - free allocation of emissions allowances and border measures. ${ }^{12}$ The expression "border adjustment" has several denominations ${ }^{13}$, but its key objective is to balance the costs between those who undertake abatement measures and non-abating countries. Therefore, in the case of aviation, the inclusion of all airlines (independently of their nationality) is a direct response to the fears of carbon leakage and unfair competition.

Moreover, the present state of multilateral negotiations is another relevant dimension for the argument of this paper. Because of high levels of uncertainty, the problem of a global regulatory gap can only be reinforced. Despite the ongoing officials talks, mostly under the Durban Platform ${ }^{14}$, concerns with the unequal

10 These events took place mainly in Washington D.C. and in Rio de Janeiro during the RIO +20 Conference in June 2012.

11 See: Carbon Trust. 2010. Tackling Carbon Leakage: SectorSpecific Solutions for a World of Unequal Carbon Prices, Carbon Trust, UK.

12 DAS, Kasturi. How vulnerable is India's Trade to Possible Border Carbon Adjustment in the EU? Journal of World Trade 46, no. 2 (2012).

13 For example: carbon border measures, border tax, carbon equalization and border carbon adjustment.

14 LIGHT, Andrew. 2011. Why Durban Matters- International Climate Process Strengthened at South Africa Talks. Available at <http://www.americanprogress.org/issues/2011/12/why_durban_matters.html> (last access May 2012). 
costs of emission reductions remain a key obstacle to advancing negotiations within the United Nations Framework Convention on Climate Change (UNFCCC). In particular, proposals from the US and the EU relating to carbon taxes before Copenhagen increased tensions between developed and developing countries. Considering potential conflicts between trade and climate regimes, emerging countries - mainly the Brazil, South Africa, India and China coalition (BASIC) - have been highly skeptical of integrating trade dimensions into the post-Kyoto agreement, with China taking the lead in contesting any attempt to link these issues. ${ }^{15}$ In this sense, the analysis of the inclusion of aviation into the ETS has to be understood under a broader perspective, which considers the turmoil in climate governance and the perception that the principle of common but differentiated responsibilities must be respected. ${ }^{16}$

Besides the concerns with competitiveness, it is important to bear in mind the historical attempt to deal with the aviation industry. While the Kyoto Protocol states that the International Civil Aviation Organization ${ }^{17}$ should take the lead on this issue, little has been done in the last two decades to collectively cope with this problem. ${ }^{18}$ At the International Civil Aviation Organization (ICAO), technical information and recommendations regarding standards have been the core of actions to limit aviation GHG emissions. However, for several years the EU has warned that, in the absence of more ambitious measures, it would include aviation in the present ETS. ${ }^{19}$ Therefore, one should not think that the EU's decision to fight against the growing aviation emissions is not necessarily new. ${ }^{20}$ For example, this issue was already evoked when the Council of Environment Ministers recognized on December 2005 that the inclusion of the aviation sector in the Community Scheme was an appropriate solution to cope with the problem of growing aviation emissions.

As a result, the Council urged the Commission to bring forward a legislative proposal by the end of 2006. Posteriorly to the Commission's proposal, the European Parliament welcomed the initiative through a resolution and recognized

15 De Paula Domingos, Nicole. 2011. The interface between climate change and trade through the eyes of Brazil. Florida Ađ'M University Law Review. Spring 2011, Vol. 6, No. 2.

16 MULLER, Benito. From Confrontantion to Collaboration? CBDR and the EU ETS Aviation dispute with developing countries. Oxford Energy and Environment Brief. February 2012.

17 "A specialized agency of the United Nations, ICAO was created in 1944 to promote the safe and orderly development of international civil aviation throughout the world. It sets standards and regulations necessary for aviation safety, security, efficiency and regularity, as well as for aviation environmental protection. The organization serves as the forum for cooperation in all fields of civil aviation among its 191 Member States." See: <http:// www.icao.int/Pages/icao-in-brief.aspx>.

18 For a broad overview of the general evolution of climate change negotiations, see: LEGGETT, Jane. 2011. A U.S. Centric Chronology of the International Climate Change Negotiations. CRS Report R40001.

19 LEGGETT, Jane; ELIAS, Bart; SHEDD, Daniel. 2012. Aviation and the European Union's Emission Trading Scheme. CRS Report for Congress.

20 See table in the annex of this paper. 
the importance of emissions trading as one potential solution. ${ }^{21}$ To clarify, the EU ETS is a cap-and-trade mechanism. This means that there is a limit on the total amount of GHG emissions that certain sectors can emit. Within this cap, companies receive allowances that can be traded between them as needed. The limit serves to give value to this transaction and to guarantee that emissions are being reduced beyond business-as-usual and, most importantly, where it costs the least. In order to reduce emissions, the total number of allowances is reduced over time. ${ }^{22}$

The new Directive is not the only instrument to combat emissions from the aviation industry. Another fundamental reference in the EU's attempts to fight climate change is the 2020 strategy. This document states that the EU should aim to set the target for reducing GHG emissions in developed countries by $30 \%$ in the context of multilateral negotiations by 2020. Irrespective of this outcome, the $\mathrm{EU}$ is compromised to the reduction of at least $20 \%$ by 2020, being 1990 the baseline. With the support of the member states since 2007, this target should be complemented by the following measures ${ }^{23}$ :

1. Improving the EU's energy efficiency by $20 \%$ by 2020 .

2. Increasing the share of renewable energy to $20 \%$ by 2020 .

3. Developing an environmentally-safe carbon geological storage policy.

Given this context, it seems relevant to mention that, in climate change, the EU sees itself as a frontrunner. ${ }^{24}$ This image of leadership, however, suffered a considerable backlash after the Copenhagen negotiations - Conference of the Parties 15 (COP-15). Leaving Denmark with the feeling it "had no friends," 25 much attention was devoted to the fact that the EU was sidelined in the most crucial moment of the negotiations, when the Copenhagen Accord ${ }^{26}$ was agreed to. ${ }^{27}$ However, what this round of negotiations made clear was that international

21 This historical background can be found at <http://eur-lex.europa.eu/LexUriServ/site/en/com/2006/ com2006_0818en01.pdf> (last access July 2012).

22 For more information, see <http://ec.europa.eu/clima/policies/ets/index_en.htm> (last access June 2012).

23 See: <http://europa.eu/legislation_summaries/energy/european_energy_policy/l28188_en.htm>.

24 "We are now ready to transform Europe into the most climate-friendly region of the world, moving towards a low-carbon, resource-efficient and climate-resilient economy." $\operatorname{COM}(2010) 86$ final. Available at $<$ http:// eur-lex.europa.eu/LexUriServ/LexUriServ.do?uri=CELEX:52010DC0086:EN:NOT> (last access July 2012). See also: De Paula Domingos, Nicole. 2007. O Protocolo de Kyoto: a União Européia na liderança do regime de mudanças climáticas. A União Européia na liderança do Protocolo de Kyoto. Mater’s dissertation. Programa San Tiago Dantas - Pontifícia Universidade Católica.

25 Interview. High Civil servant. European Commission, DG Environment. Paris, July 2010.

26 Climate Change Conference of the Parties, Copenhagen, Den., Dec. 7-19, 2009, Copenhagen Accord, art. 6, U.N. Doc. FCCC/CP/2009/L.7 (Dec. 18, 2009) [hereinafter Copenhagen Accord], available at <http:// unfccc.int/resource/docs $/ 2009 /$ cop 15/eng/11a01.pdf\#page $=4$.pdf $>$.

27 “Europe snubbed in Copenhagen?”. BBC news. December 22, 2009. Available at <http://www.bbc.co.uk/ blogs/thereporters/gavinhewitt/2009/12/s_5.html> (last access July 2012). 
climate governance is in turmoil. The first evidence for this relates to the decreased level of ambition present in the final agreement. Thus, the main message from the Copenhagen Accord was that bottom-up approaches regained legitimacy. ${ }^{28}$

In retrospective, several organizations have been trying to better cope with the impact of aviation on climate. However, it is fair to say that scientific complexity and uncertainty are major drawbacks to advance this debate. Notwithstanding the lack of consensus, scientists agree upon the need to reinforce the practice of inventories as an attempt to better quantify the impact of this sector. And yet, the fact is that no single approach exists and uncertainty is a variable to be taken into account. ${ }^{29}$ This technical complexity is certainly one of the reasons for the difficulties in reaching an agreement under the ICAO.

However, this paper will show that the fundamental difficulty in dealing with bunker fuels at present is not science uncertainty, but politics. In particular, little progress has been made in this organization because negotiations are divided between those who favor more ambitious policies and others who defend that fast-growing developing countries should not be compelled to specific targets. According to the European Federation for Transport and Environment, the negotiations under ICAO were a "lost decade." Table 1 below illustrates this $\operatorname{argument}{ }^{30}$ :

Table 1. ICAO's lost decade.

\begin{tabular}{|ll|}
\hline 2001 & $\begin{array}{l}\text { Reaffirmed opposition to fuel taxes, showing preference for the use of charges. } \\
\text { In } 2004 \text { asked Member States not to apply charges until at least } 2007 .\end{array}$ \\
\hline 2001 & Ruled out the possibility of establishing GHG emission standards for aircraft. \\
\hline 2001 & Opposed the application of closed emission trading schemes for aviation. \\
\hline 2004 & $\begin{array}{l}\text { Dismissed any possibility of establishing a global emissions trading scheme for } \\
\text { aviation, instead endorsing the inclusion of aviation in existing emission trading } \\
\text { schemes (for example, the EU ETS) }\end{array}$ \\
\hline
\end{tabular}

28 FALKNER, Robert; STEPHAN, Hannes; VOGLER, John Vogler. International Climate Policy after Copenhagen: Towards a 'Building Blocks' Approach, Global Policy 252 (2010), available at <http://onlinelibrary. wiley.com/doi/10.1111/j.1758-5899.2010.00045.x/pdf>. "From a review of the history of the 'global deal' strategy from Rio (1992) to Kyoto (1997) and beyond we conclude that this approach has been producing diminishing returns for some time, and that it is time to consider an alternative path - if not goal - for climate policy. The alternative that, in our view, is most likely to move the world closer towards a working international climate regime is a 'building blocks' approach, which develops different elements of climate governance in an incremental fashion and embeds them in an international political framework. This alternative [...] is already emerging in international politics."

29 International Civil Aviation Organization. ICAO Environmental Report: Aviation's Contribution to Climate Change. 2010.

30 Grounded: How ICAO failed to tackle aviation and climate change and what should happen now. Published to coincide with the ICAO Triennial Assembly, Montreal September-October 2010. 2010 European Federation for Transport and Environment AISBL. Page 4. 


\begin{tabular}{|c|c|}
\hline 2004 & $\begin{array}{l}\text { Imposed three-year moratorium on GHG emission charges (although it } \\
\text { continues to say that taxes are even worse). }\end{array}$ \\
\hline 2007 & $\begin{array}{l}\text { Assembly threatens to block the possibility for countries (i.e. the EU) to include } \\
\text { foreign carriers into their emissions-trading schemes. EU countries dissent. }\end{array}$ \\
\hline 2007 & $\begin{array}{l}\text { Formation of ICAO Group on International Aviation and Climate Change } \\
\text { (GIACC), to develop non-binding aspirational goals as a framework of } \\
\text { measures that member states might adopt. }\end{array}$ \\
\hline 2008/2009 & $\begin{array}{l}\text { No consensus reached in the GIACC. Some members criticize the "programme } \\
\text { of action" for not addressing Kyoto 2.2, i.e. by not focusing on emission } \\
\text { reductions. Short term "aspirational" } 2 \% \text { annual efficiency improvement goal to } \\
2012 \text { agreed. }\end{array}$ \\
\hline 2009 & $\begin{array}{l}\text { High Level Meeting (HLM) extends } 2 \% \text { efficiency goal to } 2020 \text { admitting } \\
\text { it won't result in net reductions in } \mathrm{CO}_{2} \text { from aviation sector as a whole. } \\
\text { ICAO's Conference on Aviation and Alternative Fuels endorsed the use of } \\
\text { sustainable drop-in fuels for aviation and adopted a global framework for their } \\
\text { development. }\end{array}$ \\
\hline 2010 & $\begin{array}{l}\text { Committee on Aviation Environmental Protection (CAEP 8) finally reverses } \\
2001 \text { decision, agrees to begin work on a new aircraft } \mathrm{CO}_{2} \text { standard. }\end{array}$ \\
\hline
\end{tabular}

Despite the lack of considerable progress at ICAO, critics from nonEuropean countries maintained a critical tone against the EU insisting it acted unilaterally. The anger was significant to the point that China issued a directive banning its airlines from complying with the ETS. ${ }^{31}$ Russia, India and the US are demonstrating their willingness to do the same. Such resentment became clearer in December 2011 in Delhi, when, in parallel of a meeting between the EU and the ICAO Council, 26 countries met to discuss how to oppose the European decision through what is now known as the "Delhi Declaration." 32

Posteriorly to this meeting, further work was done under the ICAO Working Paper 50, which elaborated on this declaration stating that the Aviation Directive was contradictory to Art. 2, paragraphs 2 (aviation and marine bunker fuels) and 10 (CBDR) of the UNFCCC, as well as the Chicago Convention. ${ }^{33}$ The ICAO council adopted this paper in November 2011 with 26 countries in favor and all the $8 \mathrm{EU}$ countries against, joined by Australia and Canada (originally supporters of the Delhi Declaration). Following this movement, in February 2012 another

31 China bans airlines from complying with EU ETS. February 6 2012. Available at <http://www.flightglobal. com/news/articles/china-bans-airlines-from-complying-with-eu-ets-367796/> (last access August 2012).

32 This meeting, chaired by the Indian's Ministry of Civil Aviation, had the presence of: Argentina, Brazil, Canada, China, Chile, Colombia, Cuba, Egypt, India, Japan, Republic of Korea, Malaysia, Mexico, Nigeria, Paraguay, Peru, Philippines, Qatar, Russia Federation, Saudi Arabia, Singapore, South Africa, Thailand, Turkey, United Arab Emirates and the United States.

33 For a historical review of each article of the UNFCCC, see: DEPLEDGE, Joanna. 2000. Tracing the Origins of the Kyoto Protocol: an article-by-article textual history. Technical paper. UNFCCC. FCCC/TP/2000/2. 
meeting in Moscow gave continuity to possible retaliation measures against the EU. The outcome was the "Moscow Declaration," which had as a goal to suspend or delay the "only functioning system that exists to address aviation carbon emissions." 34

It is relevant to note that the support of the United States was not consensual, but condemned, for example, by the New York-based Environmental Fund (EDF) for not having a constructive role in this process and act as an obstructionist. ${ }^{35}$ Similarly, some argue that the idea of unilateralism is a caricature of the state of the problem. As one analyst says, "countries cannot be hostage of global inaction." 36 This argument echoes the EU's most recurrent explanations for its decision, as the aforementioned lack of progress at ICAO also illustrates the need for further action.

On this subject, the year of 2004 was an important date. After another unsuccessful round of negotiations, the organization endorsed the opportunity of its member states to incorporate international aviation in their own emissionstrading scheme. As a result, the EU interpreted this document as a "green light" for passing the inclusion of aviation in 2008 into law, becoming effective in January 2012. Furthermore, Arthur Runge-Metzer, International and Climate Strategy Director at the European Commission, defended the European position stating that "business preferred emissions trading to other regulation and the airline trade body International Air Transport Association (IATA) had backed the extension of the EU ETS to cover aviation in September 2006. ICAO itself, he added, had endorsed an open emissions-trading system since 2001." This reinforces the fact that the EU's decision did not come "out of the blue."

To sum up, the perception that no progress was being made at ICAO is fundamental to understand the EU's decision to "go alone." So far, the paper showed how difficult it has been to deal with emission from the aviation sector for technical and normative reasons. In the next sections, I will examine this regulation from three different angles: legal, economical and political.

\section{Is the EU directive compatible with present international law?}

One major concern of analysts is whether the EU's legislation is consistent with a number of international accords. Three sets of concerns have been calling the attention the most. First, it is questioned whether the EU can extend its own regulations beyond its territorial jurisdiction. Second, critics of the measure have been alerting for the EU's disrespect of a number of multilateral and bilateral

34 Opponents to European airline emissions law prepare their countermeasures. New York Times. February 22, 2012.

35 BRICS, United States and others join in Delhi Declaration to oppose EU's imposition of ETS on their airlines. October 3, 2011. Available at <http://www.greenaironline.com/news.php? viewStory=1344> (last access July 2012).

36 Personal interview. Joshua Meltzer. Fellow, Global Economy and Development at Brookings. July 2012; Washington D.C. 
agreements. Finally, there are doubts about the degree of consistency between the EU's law and the World Trade Organization (WTO) rules.

In regards to bilateral and multilateral agreements, the main negative reaction came from the belief that several international rules were being infringed in the scope of the Chicago Convention, the Kyoto Protocol and the Open Skies Agreement. In the case of the Chicago Convention, the complaint is that an illegal charge or an illegal tax on aircraft operators would be imposed, which is prohibited under Article 15. Since the EU ratified the Kyoto Protocol, it should comply with the rule that says that GHG emissions from aviation must be dealt under the ICAO authority. Finally, the same argument applies for the Open Skies Agreement, which has the EU and the US agreeing to pursue emissions trading measure within the ICAO framework. ${ }^{37}$ As a whole, the main accusation is that the EU is breaching customary international law by trying to rule beyond the European Union's territorial jurisdiction.

The accusation of illegality was first brought to the London High Court of Justice by the Air Transport Association of America - an association between American Airlines and United-Continental. The London court then transferred it to the European Court of Justice (ECJ) in Luxembourg. ${ }^{38}$ Pushed to respond to these critics, the ECJ concluded in December 2011 that the scheme could not be considered a tax because it was not designed to generate revenue for the public authorities and was not a pre-established value according to any specific calendar. Instead, the price of allowances would reflect free-market forces. Furthermore, it considered that the Open Skies Agreement was not being violated, as it is meant to prohibit discrimination between American and European operators. Despite the Court's decision and the measure being validated and implemented, a number of legal difficulties still persist. ${ }^{39}$ Before exploring this topic, I must say that the interest of this paper is not to extensively tackle the legal limits of this measure. ${ }^{40}$ Because of the excessive complexity and the large scope, I will only outline the most important arguments, mostly within the WTO.

First of all, in the attempt to address the degree of consistency with the WTO, analysts usually focus on three central interrogations. One is whether EU law violates the most favored nation and national treatment obligations under the General Agreement on Tariffs and Trade (GATT). The other is whether, in

37 TUNTEG, Michael (ed.) 2012. Legal Analysis on the Inclusion of Civil Aviation in the European Union Emissions Trading System. Centre for International Sustainable Development Law (CISDL).

38 International airlines will be charged for carbon emissions, EU court rules. December 21 2011. Available at <http://www.guardian.co.uk/environment/2011/dec/21/international-airlines-carbon-emissions > (last access June 2012).

39 See the full text of the decision at $<$ http://curia.europa.eu/juris/documents.jsf?num=C-366/10 $>$. For the press release, see: <http://curia.europa.eu/jcms/upload/docs/application/pdf/2011-12/cp110139en.pdf> (last access June 2012).

40 For a comprehensive analysis on the legal issue, see: Meltzer, Joshua. Climate Change and Trade - The EU Aviation Directive and the WTO. Journal of International Economic Law. March 2012. 35 p. 
case of a WTO panel, the EU could use the articles dealing with environmental exceptions. A third point relates to the question whether the EU scheme could be considered a Border Carbon Adjustment (BCA), in other words a border tax. ${ }^{41}$ According to Bartels, the European Court of Justice ruled that the scheme does not constitute a tax, implying that the measure is non-fiscal. Therefore, he believes that it cannot be considered for the GATT purposes. In his words:

\begin{abstract}
"The fact that some of the revenue earned as a result of such a measure flows back to the state is unimportant. The EU's scheme is more similar to a law requiring motorcycle riders to purchase helmets. This is obviously a regulatory measure, and it does not cease to be one just because the state sells an initial quantity of those helmets. The point is that the compulsory purchaser retains something of value - indeed, in the case of emission allowances, this is something the value of which could increase significantly on the open market." ${ }^{.12}$ (Bartels 2012, 16)
\end{abstract}

Nevertheless, this interpretation remains inconclusive. Some analysts argue that, if the EU ETS does not impose an illegal charge under the Chicago Convention, it "imposes at least an illegal tax, because emissions are linked to the use of fuel and Article 24 of the Chicago Convention as well as the EU/US Open Skies Agreement provide that fuel shall be exempt from duties." 33

After evaluating several angles of potential incompatibilities with the WTO, Bartels suggests that the EU scheme might violate a number of obligations under the GATT and the General Agreement on Trade in Services (GATS). For example, giving selective exemption to certain airlines or countries, in case they implement a similar scheme, could infringe the most favored nation principle. However, Article XX, which allows some environmental exceptions, could justify them in light of climate change concerns. ${ }^{44}$ The obstacle, in this case, is to comply with the series of additional requirements present in the chapeau of Article XX. The most contentious issue will then be to prove that the measure is not arbitrary or unjustified discrimination. In general, the fact that countries with regulatory measures could claim an exception suggests that products from non-regulated areas will have to cope with extra costs according to the distance of the travel that goods need to arrive in Europe. In case of litigation, this could be considered

41 For an extensive analysis on these points, see: Bartels, Lorand. 2012. The inclusion of aviation in the EU ETS: WTO law considerations; Trade and Sustainable Energy Series. Issue Paper No. 6; International Centre for Trade and Sustainable Development, Geneva, Switzerland.

42 Bartels, Lorand. 2012. The inclusion of aviation in the EU ETS: WTO law considerations; Trade and Sustainable Energy Series. Issue Paper No. 6; International Centre for Trade and Sustainable Development, Geneva, Switzerland. Page 16.

43 TUNTEG, Michael (ed.) 2012. Legal Analysis on the Inclusion of Civil Aviation in the European Union Emissions Trading System. Centre for International Sustainable Development Law (CISDL), page 5.

44 Ibid. 
discriminatory. Another problematic point, which Bartels points out, relates to the risks of unintended effects of the scheme. With the objective to avoid the burdens of the new regulation, airlines could start avoiding direct flights. This would, paradoxically, create an incentive for more carbon emissions.

Finally, it is still too early to present a conclusive analysis regarding the competition distortion resulting from the EU's decision. However, some recent studies have alerted for the risk of the low impact of the regulation. According to Vespermann and Wald, "while the system will unfold both its economic and ecologic effects in the long run, the current system design will not evoke a substantial reduction of emissions from air transportation. If significant absolute reductions of environmental industry costs are intended, these reductions can only be reached by a more restrictive system design." ${ }^{45}$ Given these concerns, the next section turns to the present estimations of the financial impacts of the Aviation Directive.

\section{"It's the economy, stupid!"}

The European Commission calculated that the new Directive would increase in the costs per passenger between $€ 2$ and $€ 12$, which is significantly less when compared to the non-compliance penalty of $€ 100$ per allowance. ${ }^{46}$ However, this assessment varies. The industry, for example, normally indicates higher values and favors a global approach. In interviews with European high civil servants, the question of methodology was raised. For example, the price of the carbon tone varies and has probably an impact in the final estimated price. This is a key issue in trying to establish the real reach of this ruling.

On the tax, the EU argues that the cost for airlines is practicable and estimates that "the scheme could prompt carriers to add between $€ 4$ and $€ 24$ (US\$ 32) to the price of a round-trip long-haul flight." ${ }^{\prime 7}$ In addition, it is expected that the extra costs will not be paid by the industry, but transferred to the consumers. For the Commission, the impact on the demand is considered mild and could be mitigated by expected industry growth. ${ }^{48}$

45 VESPERMAN, Jan; WALD, Andreas. Much Ado about Nothing? - An Analysis of Economic Impacts and Ecologic Effects of the EU-Emission Trading Scheme in the Aviation Industry. Transportation Research Part A (2011) 45; pp. 1066-1076. Page 1075.

46 US voices 'objections' to EU aviation emissions ruling. Published December 22, 2011 - Updated January 2, 2012. Available at <http://www.euractiv.com/transport/us-voices-objections-eu-aviation-news-509893> (last access July 2012).

47 India, China attack EU on airline carbon tax. 14 February 2012. Available at <http://www.eubusiness.com/ news-eu/india-basic-climate.f75> (last access July 2012).

48 BARTELS, Lorand. 2012. The inclusion of Aviation in the EU ETS: WTO law considerations; Trade and Sustainable Energy Series. Issue Paper N. 6; International Centre for Trade and Sustainable Development, Geneva, Switzerland. 
While Europeans highlight the "manageable" extra cost, others argue that this is "just the beginning." As one diplomat affirms, "the costs are not negligible, because it will all depend of the future prices of carbon, which can increase considerably depending on the demand." 49 For others, the main problem is the risks of discriminatory rules under the environmental label with potential spill-over effects into other sectors already in the phase of implementation - i.e. Renewable Energy Directive, Renewable Energy, Energy Efficiency and Climate Change Program (REACH) and Restriction of Hazardous Substances Directive (RoHS). In other words, "what we observe is that regimes under environmental or sanitary justification of the EU always mix, in a very fine manner, fair arguments with unfair norms." 50

In the specific case of Brazil, interviews also revealed that the Brazilian government seemed to be more upset by the EU's decision than Brazilian airlines. Moreover, despite less vocal than China or India, Brazil signed both declarations (Delhi and Moscow) and supported all initiatives to retaliate the EU. Interestingly, an air services agreement was not signed at the last minute during the EU-Brazil Summit in October 2011. One of the reasons was a paragraph in which the EU requested a license to not be questioned about domestic measures regarding environmental actions in the aviation sector. ${ }^{51}$ This implies that significant economic effects can be a reality in the near future. In this case, the weight of the present economic crisis is a considerable variable that should be taken into account.

Yet, a relevant point of this debate is that the primary reason for resentment is not necessarily related to the costs of this new law. This research interestingly reveals that, in some cases, governments and not airlines associations are taking the lead in boycotting the compliance with the EU legislation. In conclusion, although the costs are real, my argument is that this is not what disrupted the bitterness of third countries. In particular, it is curious to note that those who are the most vocal are not necessarily the most vulnerable. China is the best example. ${ }^{52}$

\section{Normative dividend as a powerful reason for discord}

The previous sections explored the critics towards the EU Directive in global aviation mainly from the economic and legal aspects. I showed that these dimensions alone were insufficient to understand the world's reaction against the EU's measure. In this part, I am interested in developing this argument further. My goal is to demonstrate that the EU took a significant risk in approving the rule and must now deal with the unintended effects by using its persuasion power and its capacity to build international coalitions. At present, non-EU countries are teaming up to

49 Interview. Brazilian diplomat. Brazilian Embassy, Washington D.C. July 2012.

50 Interview. Brazilian diplomat. Brazilian Mission to the EU in Brussels. July 2012.

51 Ibid.

52 DAS, Kasturi. 2012. Op. cit. 
combat a decision that should not be denounced. One of the tasks of this paper is to point out the serious political implications of this decision for the EU.

To start, it is worth citing a recent press release by Lufthansa that stressed the gloomy situation of European airlines:

"According to the most recent forecast of the International Air Transport Association, Europe's airlines are headed for a loss of US\$ 1.1 billion. As late as March, the association was expecting a loss half that amount and cited the euro debt crisis and the ongoing recession in several EU countries as reasons for the worsened outlook. Add to those factors the political regulatory environment, which is undermining the competitiveness of local airlines. German Federal Transport Minister Dr. Peter Ramsauer summed up the situation in mid-June 2012, when he said: 'Aviation today is caught in a toxic mix of burdensome air travel taxes, emissions trading, and restrictions on operating hours."

This quote puts into evidence how it would be problematic if several countries decided to boycott the EU's regulation, which is not unrealistic. For example, Russia declared that overflight rights could be denied as a pressure measure. India has considered revoking the landing rights of EU airlines. This is particularly challenging for the future projections of a billion-euro future market. China has repeatedly stated its intention to impose punitive tariffs and sanctions, while threatening to cancel contracts with Airbus. The United States is trying to pass a law prohibiting US airlines to comply with the ETS. ${ }^{53}$ All these menaces are neither positive for the environment, nor for scaling up a low-carbon economy.

Furthermore, following the Copenhagen trauma, the official European position remained keen on a robust legally-binding agreement under the UNFCCC. ${ }^{54}$ However, it is remarkable how the need for building coalitions gained importance in official statements. ${ }^{55}$ Subsequently, the Copenhagen Accord, building support with different partners to reinvigorate the multilateral negotiations became vital for the EU. In this sense, the aviation industry certainly challenges the EU's ability to bring other countries to its side.

In summary, instead of collecting adherent voices to its cause, the EU provoked extremely antagonistic reactions. The BASIC countries, the US and the Alliance for Small Islands States (AOSIS) felt betrayed by the EU's behavior. In the case of the island states, the reaction is less vocal in the media but not less important. These insulated states will be affected by any decision due to their high dependence on tourism, which could particularly suffer from shifts in the price

53 Lufthansa. Policy brief. 04/2011. December 2011. Available at <http://presse.lufthansa.com/fileadmin/ downloads/en/policy-brief/12_2011/LH-PolicyBrief-December-2011-Emissions-trading2.pdf> (last access July 2012).

54 For further references, see: WBGU (2010). Climate Policy Post-Copenhagen - A three level strategy. Policy Paper no. 6, German Advisory Council on Global Change: 17.

55 See, for example, this communication: $\operatorname{COM}(2010) 86$ final. Available at http://eur-lex.europa.eu/LexUriServ/ LexUriServ.do?uri=CELEX:52010DC0086:EN:NOT (last access July 2012). 
of tickets as a result of potential increases in emissions due to newly unsustainable routes. ${ }^{56}$ The general perception is that the EU lacks authority and disregards key principles in international law.

This paper, thus, draws attention to both the effectiveness and the legitimacy challenges of the directive. Studies and interviews with stakeholders show that, instead of combating deadlock, the EU seems to aggravate the situation by reinforcing its lack of trust and transparency. For example, "if many countries were to employ unilateral measures, this could result in an undesirable fragmentation of environmental protection." ${ }^{57}$ The first unintended consequence could be the creation of incentives for conservative players (i.e. China, India and the US) to retaliate against environmental regulations. By denouncing the illegality of the rule, they are delaying a sound solution to the problem. Furthermore, some argue that the implementation of the EU ETS undermines the role of ICAO, which has a leading role in this matter according to resolution A37-19116, also signed by EU member states. ${ }^{58}$

\section{The solution}

The previous section showed high degrees of dissatisfaction with the EU's aviation directive. At present, criticism is so fierce that a global boycott has ensued. ${ }^{59}$ In a context of political stress and multilateral fatigue, one shortcoming for the EU is that its frontrunner image is being jeopardized. There are reasons to believe that losing key partners is troublesome not only for the EU as a global actor but also for the integrity of the multilateral process. As former Executive Secretary Yvo de Boer says, "a leader is only a leader if it has followers." ${ }^{60}$ Considering the present transitional moment, in which new poles of influence are rising, it is particularly problematic to behave the way that the EU has with regards to excluding key partners from the process of rule-making.

Instead of criticizing the EU for taking the first step, this section is interested in assembling a potential solution for the conflict. One unanimous answer is "finding a global solution at ICAO." However, it seems difficult to understand how, after a decade of little progress, countries can all of a sudden agree. The main point is that aviation needs to be regulated globally and not through a regional scheme. Interestingly, this viewpoint does not differ from that of the EU. Most importantly, following this wave of threats, the EU agreed to revise its decision if a global decision

56 Interview. Diplomat from the Republic of Maldives. Rio de Janeiro, June 2012.

57 TUNTEG, Michael (ed.) 2012. Legal Analysis on the Inclusion of Civil Aviation in the European Union Emissions Trading System. Centre for International Sustainable Development Law (CISDL), page 14.

58 Ibid, page 17.

59 Lufthansa Press Release, July 2012. Available at <http://presse.lufthansa.com/fileadmin/downloads/en/ policy-brief/07_2012/LH-PolicyBrief-July-2012-News.pdf> (last access July 2012).

60 Interview with Yvo de Boer, former Executive Secretary of the UNFCCC. Rio de Janeiro, June 2012. 
is reached. There are two problems with this approach. First, non-EU countries feel that they have to negotiate under pressure in order to find an agreement and avoid paying penalties. As a European Diplomat states, "the problem is that countries feel that they are negotiating with a gun in the head." ${ }^{61}$ Several stakeholders, confirming the level of discomfort, repeated this line of reasoning. Second, there are signs that the EU also feels uncomfortable for being pressured to change their own law as "backing off now would symbolize a lack of credibility." ${ }^{2}$ Moreover, it is difficult to conceive a suspension of a law that has already been approved.

The EU's decision certainly forced ICAO to speed up negotiations. At present, four options, mutually non-exclusive, are on the table: mandatory offsetting, offsetting complemented by a revenue-generating mechanism, a cap-and-trade scheme, and an emissions-trading baseline and credit system. However, ICAO works in three-year cycles. The next round of decisions will be at the General Assembly in 2013. Given these procedural constraints, experts point to the unlikelihood of a market-based global system before $2015 .{ }^{63}$ This implies that a solution will most likely not be reached in the near future. One of the fundamental problems continues to be a conflict between the UNFCCC, which argues for a principle of common but differentiated responsibilities, and ICAO's principle of equality among member countries.

The first great challenge of policymakers is to accommodate both principles according to circumstances and capabilities. This conflict is far from being new. In particular, it is interesting to note that, despite the union of several countries behind the Delhi and Moscow Declarations, the position of US airlines differs from those of developing countries. As argued by Meltzer, "for the US, the EU legislation should not be discriminatory. All countries must be treated equally." 64 In objective terms, the legislation has little chances to change if no other ambitious decisions occur at ICAO. Therefore, airlines are progressively concerned about how they can best comply with the measure and avoid escalating penalties. One of the alternatives for the industry is to force its own governments to adopt similar regulatory frameworks in order to gain exemption rights.

Finally, it seems clear that a real solution can only be found via negotiations. There are signs that the EU's action added some fuel to the fire. However, old dilemmas seem to continue to block a multilateral consensus. The question whether the EU scheme will be postponed or not remains open. What is clear, instead, is that Europe is not in a position to be indifferent to the escalation of conflict. Neither is the environment.

61 Personal interview. European diplomat. Transport Sector. EU Delegation. Washington D.C. July 20, 2012. 62 Ibid

63 Attention focuses on ICAO as emission-trading row rumbles on. April 2012. Available at <http://www. flightglobal.com/news/articles/in-focus-attention-focuses-on-icao-as-emission-trading-row-rumbles-on-371009/> (last access July 2012).

64 Personal interview. Op. cit. 


\section{Conclusion: what is the lesson for the EU?}

This paper explored the reasons for global resentment against the EU's aviation directive. Drawing from the historical attempts to regulate the aviation sector with respect to GHG emissions, the analysis maps out the problem from three different angles: legal, economical and political. The most substantive conclusion is that the EU's unilateral action created a normative divide among its main trading partners, putting at risk its future capacity to persuade these countries to take more ambitious actions in climate change. This is especially counterproductive given the present state of multilateral negotiations, which continues to advance at an unsatisfactory pace.

While the EU had the right intention, the method it chose was unfortunate. By sending a wrong sign to its partners, the EU aggravated the Copenhagen trauma and the image of a leader "without followers." The main lesson is perhaps that climate change negotiations need fewer sticks and more carrots. I showed that the EU gained very little in trying to solve a complex problem without its partners. Besides accusations of illegality and unilateralism, the EU put at risk the creation of a patchwork of bureaucratic and conflicting rules, which, ultimately, could not properly address its main goal: to cut aviation emissions. Unsurprisingly, this is only one example of a deeper problem related to the interface between trade and climate rules. International shipping, for instance, also faces similar challenges to those of the aviation industry. ${ }^{65}$

"Make climate change about bills, not bears." ${ }^{66}$ This phrase summarizes well the evolution of the climate change debate. Not too long ago, this issue was stigmatized by ecological images in relation to the protection of species, most notably the polar bear. Today, governments have realized how strategic this issue has become. As one of the most important challenges of our century, the debates have gained importance because of their strong link with competitiveness policies. There is a shifting perception that climate change is shaping the daily life of other powerful organizations, most notably the WTO. Attempts to deal with potential conflicts between trade and climate regimes lost force in 2010, after building momentum in Copenhagen. This proved to be only a momentarily pause in a problem that was only starting to gain prominence. ${ }^{67}$

Lastly, the next chance of better addressing this problem will be in Doha, Qatar, in the occasion of the $18^{\text {th }}$ Conference of the Parties. There, countries will have another chance to find common solutions for problems that are now deeply

65 After aviation tax, EU mulls carbon levy on shipping. Available at <http://articles.timesofindia.indiatimes. com/2012-04-02/india/31274958_1_carbon-tax-eu-decision-chinese-airline> (last access July 2012).

66 The Guardian. April 2, 2012.

67 De Paula Domingos, 2011. Op. cit. 


\title{
interconnected. If they succeed, the symbolism of the city should inspire the disentanglement of the moribund Doha Round on Development.
}

\author{
Received August 19, 2012 \\ Accepted September 15, 2012
}

\begin{abstract}
The European Union's (EU) decision to include aviation into the Emissions Trade Scheme was heatedly contested. Countries around the world, but mainly the Brazil, Russia, India, China and South Africa group (BRICS) and the US, denounced the EU's initiate as illegal and unilateral. Following a decade of frustrated negotiations at the International Civil Aviation Organization (ICAO), this paper interrogates why such measure, in principle climate-friendly, inspired so much global resentment. I argue that concerns with competitiveness and risks of legal inconsistency are important, but insufficient elements to explain the core of the conflict. The paper suggests that the EU was strongly criticized because third countries perceived this action as an imposed solution, which fostered an environment of distrust. Therefore, I claim that the problem has more to do with a normative divide than with a substantive divergence on what should be done regarding aviation emissions. My analysis is informed by the present literature on the links between trade and climate change, but gives particular weight to first-hand information through interviews with key stakeholders. The paper is divided in three parts. First, it presents the scope of the EU directive in historical perspective. Second, it explores the EU's measure through three different angles: legal, economical and political. The final part explores some possible solutions to overcome these divergences.
\end{abstract}

Keywords: Aviation Directive; climate change; European Union.

\section{Resumo}

A decisão da União Europeia (UE) de incluir a aviação no Esquema de Comércio de Emissões - Emissions Trade Scheme (ETS) - foi fortemente contestada. Os países ao redor do mundo, especialmente o grupo Brasil, Rússia, Índia, China e África do Sul (BRICS) e os EUA, denunciaram a iniciativa da UE como ilegal e unilateral. Após uma década de negociações frustradas na Organização da Aviação Civil Internacional (OACl), este artigo questiona por que tal medida, a principio climaticamente amigável, inspirou tanto ressentimento mundial. Defendo que as preocupações com a competitividade e os riscos de inconsistência legal são importantes, mas elementos insuficientes para explicar o cerne do conflito. Este artigo sugere que a UE foi fortemente criticada porque os países terceiros perceberam esta ação como uma solução imposta, que fomentou um ambiente de desconfiança. Portanto, afirmo que o problema tem mais a ver com uma divisão normativa do que com uma divergência substancial sobre o que deveria ser feito com respeito às emissões de aviação. Minha análise tem por base a literatura atual sobre as ligações entre o comércio e a mudança climática, mas também dá particular importância às informações de "primeira mão", através de entrevistas com os principais interessados. O artigo está dividido em três partes. Primeiramente, apresenta-se o escopo das diretivas da UE em uma perspectiva histórica. Segundo, exploram-se as medidas da UE através de três ângulos diferentes: o legal, o econômico e o político. A parte final explora algumas possíveis soluções para superar essas divergências.

Palavras-chave: Diretiva de Aviação; mudança climática; União Europeia. 


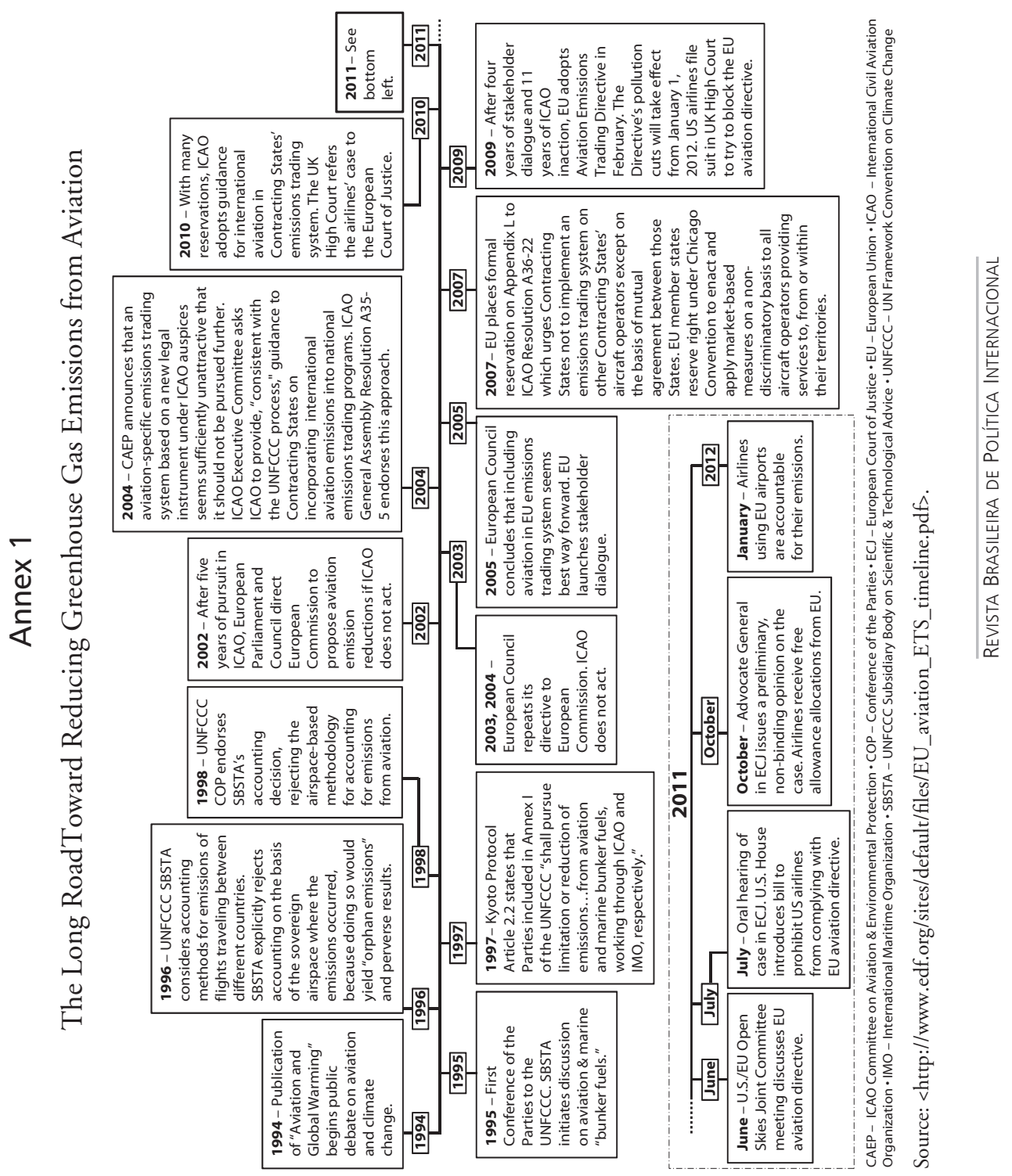

